UDC 811.111

DOI https://doi.org/10.26661/2414-1135-2020-80-2-47

\title{
THE NOMENCLATURE OF WAYS OF PRESENTATION IN THE TEXTS OF OFFICIAL DISCOURSE GENRES
}

\author{
Shapa L. N. \\ Candidate of Philological Sciences, Associate Professor, \\ Senior Lecturer at the Department of Foreign Languages \\ Odessa National Polytechnic University \\ Shevchenko ave., 1, Odessa, Ukraine \\ orcid.org/0000-0002-3502-4577 \\ shapa.od@gmail.com \\ Tsapenko L. E. \\ Candidate of Philological Sciences, Associate Professor, \\ Senior Lecturer at the Department of Foreign Languages \\ Odessa National Polytechnic University \\ Shevchenko ave., 1, Odessa, Ukraine \\ orcid.org/0000-0002-5088-2393 \\ ellebeva@gmail.com \\ Kudinova T. I. \\ Assistant Professor at the Department of Foreign Languages \\ Odessa National Polytechnic University \\ Shevchenko ave., 1, Odessa, Ukraine \\ orcid.org/0000-0003-3302-6699 \\ kudinova.tamara@gmail.com
}

Key words: speech acts, text corpus, token, language means, extra linguistic factor, imperativeness.
The article considers one of the problems of discourse science - various ways of presentation of information used in the texts of official discourse. The description of these methods became possible after the text corpora compilation was carried out on the basis of works that belong to the official discourse. The corpora include texts of the following genres: official correspondence, legal procedural documents, instructions for the operation of cars, formulas of inventions (patents). The total volume is 200 thousand tokens.

The text corpora analysis has shown that almost all methods of data presentation are inherent to the official discourse: narration, reasoning, message, obligatory-prescriptive method, description, informing, etc.

For the implementation of each method of presentation in the official style texts certain speech means are used which make it possible to fulfill the task of forming a particular method. For example, the characteristics inherent to the narrative manner of presentation have been discovered and described: the use of verbs in the past tense, subordinate sentences, direct word order, etc .; reasoning: the usage of the word "thus" which is a means of inter-phrase communication to ensure a logical sequence of reasoning, etc.; the obligatory-prescriptive method: the usage of verbs in the imperative mood, etc.

It has been determined what specific methods of presentation are characteristic for different genres. So the texts of official correspondence genre and formulas of invention are characterized by such a way of presentation as description. In the texts of military documents the type of presentation is dictated by the purpose of the text, i.e. motivation for action especially for executive parts. Although there is an opinion among linguists that there is no imperativeness in the official discourse texts the materials of our text corpora indicate that it is the imperativeness that underlies certain genres of this discourse (for example, in the texts of instructions for the operation of cars).

The results of the analysis of the text corpus of the official discourse genres allow us to assert that official discourse is characterized by all types of presentation depending on the genre, type of text and its parts. 


\title{
НОМЕНКЛАТУРА СПОСОБІВ ВИКЛАДЕННЯ В ТЕКСТАХ ЖАНРІВ ОФІЦИЙНО-ДІЛОВОГО ДИСКУРСУ
}

\author{
Шапа Л. М. \\ кандидат філологічних наук, доиент, \\ дочент кафедри іноземних мов \\ Одеський національний політехнічний університет \\ пр. Шевченка, 1, Одеса, Україна \\ orcid.org/0000-0002-3502-4577 \\ shapa.od@gmail.com \\ Цапенко Л. Ю. \\ кандидат філологічних наук, дочент, \\ дочент кафедри іноземних мов \\ Одеський національний політехнічний університет \\ пр. Шевченка, 1, Одеса, Україна \\ orcid.org/0000-0002-5088-2393 \\ ellebeva@gmail.com \\ Кудінова Т. I. \\ старший викладач кафедри іноземних мов \\ Одеський національний політехнічний університет \\ пр. Шевченка, 1, Одеса, Україна \\ orcid.org/0000-0003-3302-6699 \\ kudinova.tamara@gmail.com
}

\begin{abstract}
Ключові слова: мовний акт, текстовий корпус, слововживання, мовні засоби, екстралінгвістичний фактор, імперативність.
\end{abstract}

Стаття розглядає одну з проблем дискурсології, а саме - різні способи викладу, використовувані в текстах офіційно-ділового дискурсу. Опис цих способів став можливим після компіляції текстових корпусів, проведеної на основі творів, які належать до офіційно-діловому дискурсу. До складу корпусів увійшли тексти наступних жанрів: службова переписка, судово-процесуальні документи, інструкції з експлуатації автомобілів, формули винаходів (патенти). Загальний обсяг склав 200 тис. слововживань.

Аналіз текстових корпусів показав, що офіційно-діловому стилю притаманні практично всі способи викладу: розповідь, міркування, повідомлення, опис, інформування та інші.

Для реалізації кожного способу викладу в текстах офіційно-ділового стилю використовуються певні мовні засоби, що дозволяють виконати завдання формування того чи іншого способу. Наприклад, були виявлені й описані характеристики, властиві оповідній манері викладу: вживання дієслів в минулому часі, додаткових пропозицій, прямий порядок слів та інші; міркування: вживання слова thus, що є засобом міжфразового зв'язку, для забезпечення логічної послідовності міркування та інші; розпорядчий спосіб: використання дієслів у наказовому способі та інші.

Було визначено які саме способи викладу характерні для різних жанрів. Так, текстам жанрів службового листування і формул винаходів властивий такий спосіб викладу, як опис. У текстах бойових документів тип викладу диктується призначенням тексту, тобто спонукання до дії, особливо для виконавчих його частин. Хоча існує думка серед лінгвістів, що в текстах офіційно-ділового стилю відсутня імперативність, матеріали нашого текстового корпусу свідчать про те, що в основі певних жанрів цього стилю лежить саме імперативність (наприклад, у текстах інструкцій з експлуатації автомобілів).

Результати аналізу текстового корпусу жанрів офіційно-ділового дискурсу дозволяють стверджувати, що офіційно-діловому стилю властиві всі види викладу залежно від жанру, типу тексту і його частин. 
The formation of any type of discourse occurs in the process of speaking during language functioning on the basis of communicative task fulfillment, i.e. the purpose of statement, which is a kind of "push" for the functional language restructuring $[1 ; 2]$.

Thus when creating texts of a certain type of discourse the selection and combination of linguistic means are determined by extra linguistic factors one of which is the form of speech. The form of a speech work is determined by a communicative task; its form is usually influenced by the interaction of subjective and objective elements [3].

For example in an official speech the main task is to achieve an agreement between the parties: organizations, institutions, governments, society and its members, etc. This function serves as a discourseforming beginning in the creation of official documentation.

The purpose of this article is to present the different ways of presentation used in the texts of official discourse.

The material is text corpora that belong to four genres included in the official discourse: official correspondence (taken from the correspondence of the British Council with teachers of universities in foreign countries (British Council Correspondence), judicial procedural documents (texts of the judicial documents of the Administrative Tribunal of the International Labor Organization (ILO) in the collection "Judges of the Administrative Tribunal of the International Labor Organization"), the texts of operating instructions for Toyota vehicles and inventions (patents) (the texts containing formulas of inventions in physics and radio electronics extracted from the licensed sources). The total volume was 200 thousand tokens, texts of each genre included samples of 50 thousand word usages.

The subject of the research is the types of speech acts that can be distinguished in the texts of various genres of official discourse.

It is known that the most common speech acts are as follows: locutionary, illocutionary and perlocutionary with the help of which the communicative optimum of the text can be achieved $[4 ; 5 ; 6 ; 7 ; 8]$ and which define the text-forming categories. The main thing in organizing the speech semantics of the official discourse is the perlocutionary act. It is considered as an impact on the thoughts and feelings of audience, on the deeds and actions of people. In texts this factor can be expressed in different ways of presentation narration, reasoning or description.

However some scholars dispute the existence of these speech acts in the given discourse. Since official and business texts, according to researchers, are written in order to "convince and win" $[9 ; 10]$, they believe that official and business speech is not inherent in these ways of presentation, that it has its own special way of presentation, namely the obligatory-prescriptive one which dictates its own language means $[11 ; 12]$.

Nevertheless, it seems more fair to the authors to believe that all methods of presentation are inherent in official discourse $[13 ; 14]$. So, it is not unfounded in our opinion, the point of view according to which narrative sentences in official and business texts contribute to formality, objectivity of presentation, static character, lack of emotionality $[15 ; 16]$, i.e. the formation of one of the main features of the official style.

To confirm (or deny) these two opposing points of view the authors turned to the text corpora of the above-mentioned genres of official discourse in order to distinguish the relevant examples. Examples from the text corpus of the International Labor Organization (ILO) court documents have showed the following. Already the first of them is an example of a narrative manner of presentation, as evidenced by the characteristics inherent in this type of presentation: the use of verbs in the past tense (volunteered, answered, wrote), additional sentences, direct word order: She volunteered her services. By her account she wrote two letters to that effect from London, one on the 12 February and the other on the 6 March 1979. On the 11 April the FAO answered that she was unlikely to be appointed and that successful candidates from outside commuting distance of Rome would be given local status. (Judgements of Administrative Tribunal, № 485, p. 61).

Here we also find another way of presentation reasoning: Thus, not only did the complainant offer her services, but she took the tests of her own accord, knowing full well that she would not get non-local status. Nor did she make repayment of any of her own acceptance of appointment. Thus, it cannot be said that the payment she is now claiming was required in order to recruit her. (in the same place).

The following means are used to express this way of presentation. To provide a logical sequence of reasoning the word "thus" is used which is a means of interphrase connection. For more convincing reasoning the author resorts to expressiveness, demonstrated in these sentences by inversion: nor did the complainant offer вместо: the complainant did not offer; nor did she make repayment вместо: she didn't make repayment, full well вместо very well или просто well.

Then the texts of the genre of official correspondence were taken as an object of analysis. It was found that they are also characterized by a wide variety of ways of presentation. Let's give an example:

1. I am sorry to have delayed so long in writing to thank you for the lecture which you so kindly agreed to give to the members of our Diploma class...

With the letter I am enclosing a cheque for five guineas which I am pleased to be able to offer you as an honorarium. 
(British Council Correspondence)

The function of this letter from the Department of Education is a message hence the narrative method of presentation.

The next sample is of an obligatory-prescriptive nature despite the fact that it is only a form that must be filled out by addressee:

2. University of London

Summer Vacation Course in English for foreign students

Please send (strike out what you do not require)

... forms of Application for Admission and Accommodation

... farther copies of the Prospectus

... Regulations for Certificate Examination

$\mathrm{Mr}$

Name Mrs...

Miss

Nationality...

Address in full...

(British Council Correspondence)

The obligatory-prescriptive character is expressed here by verbs in the imperative mood: send, strike out.

The following sentence is characterized by another way of presentation - description:

On this excursion we shall visit this historic Palace of Linglithgow, where Mary Queen of Scots was born, and the imposing castle of Stirling, somewhat similar to Edinburgh Castle, perched on volcanic rock fine views on the countryside. (British Council Correspondence)

This sentence is a part of a cover letter and its descriptive nature is dictated by an extra linguistic factor - the desire to convince an addressee of the need to make a tour. Hence - the use of attributive clauses and adjectives: imposing, similar, volcanic, fine.

Let us give another example from the texts of the genre of inventions where we are dealing with the description of a device. The descriptive manner of presentation in this sentence is achieved by attributive subordinate clauses, participial phrases, as well as multi-component prepositive attributive constructions: program generating unit, respective optical paths.

For example, A method and apparatus for programming equipment for the secured transmission of messages for example by enciphering and deciphering these messages, in which a program is passed to a transportable unit, and from the transportable unit to the transmission equipment, by way of respective optical paths ... (Refer. information. 1982, No. 11, issue 114).

The above examples show that official style is characterized by different ways of presenting which depend not only on the type of document but also on its parts. Thus in the texts of military documents the type of presentation is dictated by the purpose of the text, i.e. depends on whether the text is informative, prompting or persuasive or simply a reference. For the informational part, for example, narrative sentences are characteristic, for the executive - imperative, for the providing - narrative and imperative [12].

The usage of the narrative manner of presentation is observed in the ascertaining parts of the decree [2, p. 177].

When considering this problem one cannot but dwell on the formal-logical way of presentation which is based on imperativeness. There is a point of view that the imperative form is not characteristic for the official discourse and that it is replaced by the indicative form of the verb [16, p. 17]. However the materials of our text corpora indicate that the basis for certain genres of this style is precisely the imperativeness (for example, in the texts of Instructions). Here are some examples: Check the electrical connections of tightness... Loosen the adjusting bolt locknut...Tighten the locknut while holding the bolt so that it cannot turn. /Instructions/

Thus we believe that all types of presentation are inherent in the official discourse depending on the type of text and its parts. However the genres of official speech are so multifaceted that the existing works, in our opinion, do not reflect the full depth of the problem, and therefore it needs further additional research.

All of the above allows us to draw the following conclusions.

1. Of all the known speech acts - locutionary, illocutionary and perlocutionary - the perlocutionary act is the only which is realized in the texts of official discourse.

2. Discussions among scientists about the ways of expressing the perlocutionary act in the texts of the official discourse have led to the need to investigate this problem on the basis of text corpora of four genres of the official style: office correspondence, legal procedural documents, car operating instructions, invention formulas.

3. The analysis of the text corpora has shown that almost all ways of presentation are inherent in the official discourse: narration, reasoning, message, the obligatory-prescriptive way, description, informing, etc.

4. For the implementation of each method of presentation in the texts of the official discourse, certain speech means are used to complete the task of forming the given method.

Thus we believe that all types of presentation are inherent in the official discourse depending on the type of text and its parts. However the genres of official speech are so multifaceted that the existing works, in our opinion, do not reflect the full depth of the problem and therefore it needs further additional research. 


\section{BIBLIOGRAPHY}

1. Стрелковский Г.М. Теория и практика военного перевода. Москва, МО СССР. 1979. 271 с.

2. Кожина М.Н. Стилистика языка. Москва, Просвещение, 1983. 222 с.

3. Львовская 3.Д. Теоретические проблемы перевода. Москва, Высш. школа. 1985. 231 с.

4. Austin J.L. How to do things with words. Oxford University Press, 1962. $221 \mathrm{p}$.

5. Searle J.A taxanomy of illocutionary acts. Expression and meaning. Cambridge, Camridge University Press. 1979. 306 p.

6. Сидоров Е.В. Системность речевой семантики. Система языка и перевод: сб. трудов МГУ. Москва. 1983. С. 99-114.

7. Кобозева И.М. Теория речевых актов как один из вариантов теории речевой деятельности. Новое в зарубежной лингвистике : сб. научных трудов. Москва, Прогресс. 1986. Вып. 17. 422 с.

8. Беляева Е.И. модальность в различных типах речевых актов. Филологические науки: сб. трудов. НДВШ. 1987. №3. С. 64-68.

9. Fortenay H. Le Bonne correspondence. Paris. 1966. $168 \mathrm{p}$.

10. Ушаков А.А. Очерки законодательной стилистики: сб. науч. трудов Пермского университета. Пермь. 1967. 207 с.

11. Лященко Т.К. Явление обособления в функционально-стилистическом аспекте : дис. ... канд. филол. наук: спец. 10.02.04. Москва, 1982. $179 \mathrm{c}$.

12. Нелюбин Л.Л. Перевод боевых документов армии США. Москва, МО СССР. 1971. 335 с.

13. Рахманин Л.В. Стилистика деловой речи и редактирование служебных документов. Москва, Высш. школа. 1982. 238 с.

14. Вольская И.С. Дифференциальные признаки официально-делового стиля на синтаксическом уровне : автореф. дис. ... канд. филол. наук : спец. 10.02.04. Москва, 1966. 15 с.

15. Слепович В.С. Просодия повествования в английском цстном тексте официального и непринужденного стилей : автореф. дис. ... канд. филол. наук: спец. 10.02.04. Минск. 1985. $21 \mathrm{c}$.

16. Калюжная В.В. Стиль англоязычных документов международных организаций. Киев, Наук. думка. 1982. 120 с.

\section{REFERENCES}

1. Strelkovsky G.M. (1979) Theory and practice of military translation [Teoriya i praktika voennogo perevoda]. Moscow, USSR Ministry of Defense. 271 p.

2. Kozhina M.N. (1983) Language stylistics [Stilistika yazyka]. Moscow, Education. 222 p.
3. Lvovskaya Z.D. (1985) Theoretical problems of translation [Teoreticheskie problemy perevoda]. Moscow, Higher school. 231 p.

4. Austin J.L. (1962) How to do things with words. Oxford University Press. 221 p.

5. Searle J. (1979) A taxanomy of illocutionary acts. Expression and meaning. Cambridge, Camridge University Press. 306 p.

6. Sidorov E.V. (1983) Systematicity of speech semantics. Language system and translation [Sistemnost rechevoy semantiki. Sistema yazyka i perevod]: Collection of scientific works of Moscow State University. Moscow. P. 99-114.

7. Kobozeva I.M. (1986) The theory of speech acts as one of the variants of the theory of speech activity [Teoriya rechevykh aktov kak odin iz variantov teorii rechevoy deyatelnosti]. Novoe v zarubezhnoy lingvistike: collection of articles, scientific papers. Moscow, Progress. Issue 17. 422 p.

8. Belyaeva E.I. (1987) Modality in various types of speech acts [Modalnost v razlichnykh tipakh rechevykh aktov]. Filologicheskie nauki : Collection of scientific works. No. 3. P. 64-68.

9. Fortenay H. (1966) Le Bonne correspondence. Paris. $168 \mathrm{p}$.

10. Ushakov A.A. (1967) Essays on legislative stylistics [Ocherki zakonodatelnoy stilistiki]: Proceedings of the Permian University. Perm. 207 p.

11. Lyashchenko T.K. (1982) The phenomenon of isolation in the functional and stylistic aspect [Yavlenie obosobleniya $\mathrm{v}$ funktsionalno-stilisticheskom aspekte] : Dis. ... cand. philol. Sciences : spec. 10.02.04. Moscow.179 p.

12. Nelyubin L.L. (1971) Translation of military documents of the US Army [Perevod boevykh dokumentov armii SShA]. Moscow, USSR Ministry of Defense. $335 \mathrm{p}$.

13. Rakhmanin L.V. (1982) Stylistics of business speech and editing of office documents [Stilistika delovoy rechi i redaktirovanie sluzhebnykh dokumentov]. Moscow, Higher school. 238 p.

14. Volskaya I.S. (1966) Differential signs of the official business style at the syntactic level [Differentsialnye priznaki ofitsialno-delovogo stilya na sintaksicheskom urovne] : abstract. dis. ... cand. philol. Sciences : spec. 10.02.04. Moscow. 15 p.

15. Slepovich V.S. (1985) Prosody of narration in the English text of the official and unconstrained styles [Prosodiya povestvovaniya $\mathrm{v}$ angliyskom tsstnom tekste ofitsialnogo i neprinuzhdennogo stiley] : abstract dis. ... cand. philol. Sciences : spec. 10.02.04. Minsk. 21 p.

16. Kalyuzhnaya V.V. (1982) Style of English-language documents of international organizations [Stil angloyazychnykh dokumentov mezhdunarodnykh organizatsiy]. Kiev, Nauk. dumka.120 p. 